\title{
Forum
}

\section{"I often find myself now basing my analysis very much on what Kalecki himself wrote sixty or seventy years ago«}

\author{
Interview with Malcolm Sawyer*,**
}

Malcolm, our first set of questions is about your career in retrospective. You have been a professional economist for more than

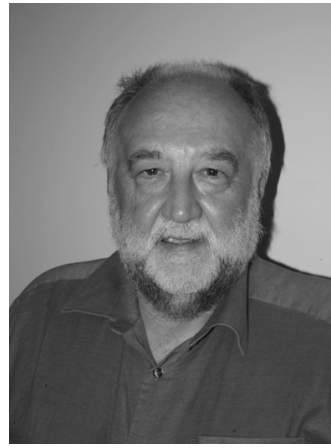
40 years. What was your motivation to become an economist, how did you get in contact with heterodox economics and what were the major steps in your career as a professional economist?

I started my academic studies as a mathematician, so when I went to Oxford in I963, it was to do a degree in mathematics. My interests though, were always in politics and economics, those things about how the world works, what factors affect unemployment and those kinds of issues. I went into mathematics because I was good at it at school and it seemed like the right route to take. Then I switched to economics, studying a masters' in the London School of Economics. At that time, the atmosphere in economics was a very Keynesian one, so I picked up on ideas to do with Keynesian economics. It was also the time of the student unrest and the revival of radical political economy. So I was coming into contact with those sorts of ideas, and it was interacting with the political debates at the time. In one sense I was always in touch with heterodox economics because it had a broader audience than it does now and one was always coming into contact with it. Those ideas, in all sorts of ways, were very attractive. The involvement in heterodox economics, from my point of view, came about partly because of the people I knew, partly because of the atmosphere at the time, and partly because of the debates at the time.

Retrospectively, would you do anything different in your career or would you follow the same path?

Well, the path one follows is never very planned. It's all sorts of accidents and interests one takes in all sorts of directions, so it's never very planned. Being a post-Keynesian, one has

* Malcolm Sawyer is Emeritus Professor of Economics, Leeds University Business School, University of Leeds, UK. He is managing editor of International Review of Applied Economics, on the editorial board of a range of journals, co-editor of the series International Papers in Political Economy and editor of the series New Directions in Modern Economics. He has published widely in the areas of post Keynesian and Kaleckian economics, industrial economics and the UK and European economies.

** We would like to thank Rory Tews for the transcription of the interview.

(C) INTERVENTION 9 (I), 20I2, 5-I2 
to treat the future as highly uncertain and not trying to formulate plans! There are all kinds of things I wish I had studied or worked on along the way. But in terms of the general way that things have gone, I can't think of any major changes I would have made. Looking back on all sorts of mistakes one makes in terms of directions, there's no way to say »If only I'd not done that!".

\section{What would be your career advice for young heterodox economists?}

Firstly to think very carefully about what it is that you want to achieve, or why it is that you are a heterodox economist. Because you have to face it that, all other things being equal, you are not going to have such a successful academic career as if you followed a more mainstream approach. You are in some ways shutting yourself off from certain advancements. You have to go down that heterodox route because you think it offers the best insights, the best explanations of how the world works and how the world can be in some sense improved. The second point would be to try to find a place to work where you are comfortable, where you have a lot of interaction with people of a like mind. If you feel that heterodox economics has maybe not the answers, but the right sort of framework in which to go, then that is what you have to do because you think it is right rather than being what will advance your career.

That fits very well with the second set of questions which deals with the development of heterodox economics and mainstream economics. What is your major criticism of mainstream economics, and do you think it has become any better in its most recent form as New Consensus Economics?

In many respects the main criticisms of mainstream economics, at least of the Neo-classical version, is its reliance on the so-called rational economic man, utility maximisation, rational expectations and thus being generally unconcerned with institutions, arrangements with history. That starting perspective, that essential reliance on rational economic man in the context of, broadly speaking, competitive markets leaning in the direction of equilibrium with optimal outcomes is the fundamental problem I have with mainstream economics. In many respects the New Consensus Macroeconomics is a step back from some of the elements in New Keynesian and certainly a step back from the Keynesian economics which I grew up with in the I960s. I see the New Consensus as taking macroeconomics firmly back into rational expectations, utility maximisation, inter-temporal budget constraints which then tend to build in all kinds of results such as Say's Law and those sort of things. Of course there are some technical tricks with the New Consensus, there are some advancements, such as that money is endogenous, but in most other respects it is a step back in terms of embedding macroeconomics in this world of rational expectations and utility maximisation.

What role does Michel Kalecki's economics play in your conception of economics, and how important have his ideas been in shaping your own thinking?

I think his general approach to economics, his thinking on macroeconomics, his approach to a whole variety of issues in macroeconomics have strongly influenced me and I often find myself now basing my analysis, for example, of the present financial crisis and the role of fiscal policy very much on what Kalecki himself wrote sixty or seventy years ago. In that 
sense his ideas and his approach have strongly lodged themselves in my mind so that when I come to look at issues such as fiscal policy I often end up pulling out his ideas from the back of my mind and applying them to the present situation. His whole thinking about macroeconomics has strongly influenced the way I now approach it, and I find myself sometimes thinking that I have developed my own idea on some issue when I find that it has echoes in the work of Kalecki and it has been lodged in my mind and come back to the surface. There are other authors, such as Kaldor, who have had quite a lot of influence on the way that I think about things, but Kalecki would have to be the prime influence.

Apart from Kaldor, are there others that you would like to name?

I guess some aspects of Keynes, though maybe not that much. Probably the work of Geoff Harcourt has also influenced some of my thinking.

If you think about the development of post-Keynesian economics, especially over the past thirty years or so, do you think there has been progress, and what do you think are the main open questions that have not been successfully solved? Also, and connected to that, what are the main reasons why post-Keynesianism did not succeed in convincing the majority of economists? There was a time when post-Keynesian economics could maybe have become the mainstream, but that was not the case, do you have any ideas as to why?

I fluctuate as to whether we have that much progress or not. To some extent I can think of areas such as the analysis of the monetary system and the creation of money where progress has been made. Other areas, perhaps on the more micro-oriented side, such as the way firms approach pricing or investment, those sort of issues have come up within the macroeconomics area where I cannot see that we have made very much progress at all. That may be because the ideas we came up with thirty years or more ago were satisfactory anyway, but in these areas not very much progress has been made. The other areas where we have realised the importance of decision-making under uncertainty, our views about the future and the way that decisions were made, and where we were always very critical of rational expectations, optimisation and those sort of things, I do not think much progress has been made in terms of understanding how decisions are made, what the influences at work are, and how that could be represented particularly in macroeconomic analysis. There are, no doubt, other areas such as behavioural economics in which there have been some advances but those have not come from post-Keynesian economics. We could be criticised for not having taken those on board. Particularly in the area of macroeconomics, when you come to teaching it to students, you have to say something about how people make decisions, you have to have some replacement for rational choice, and that we have not succeeded in formulating it in a way that can be put over. Paradoxically, in areas like pricing and investment, the evidence on what influences pricing or investment is so overwhelmingly supportive of the general views that post-Keynesians have put forward as against the orthodox views. It is surprising that we have not been able to establish that in terms of the way that it feeds into our macroeconomic analysis. Also, certainly in the UK, we are quite pessimistic about the development of post-Keynesian economics, particularly the extent to which we are able to 
reproduce our ideas and train the next generation. In contrast, if you come to conferences like the Berlin, Bilbao or Dijon conference, it is much more optimistic in the sense that there is clearly a lot of involvement of the next generation and a development of ideas there.

What are the main justified criticisms to be faced by post-Keynesians today? You said you were surprised that post-Keynesians could not convince the majority, do you think there are some structural reasons why post-Keynesianism did not become the mainstream?

I would put it the other way round and think in terms of what was this Keynesian economics which was dominant in the 1960s, and how it was then replaced by the new classical macroeconomics and then later New Keynesianism and New Consensus. I still find it very difficult, looking back, to understand how that happened because, for example, the idea of rational expectations seems on one level so obviously wrong, intuitively we know that we do not have rational expectations ourselves. If we generalise our own experience, we know that having a working economic model in our head with which we can solve expectations just seems so false. In another direction how could it be that new classical macroeconomics could come to the fore and establish itself in the context of the late 1970s and early 1980s where unemployment was rising to very substantial levels, and here was an approach to macroeconomics which denied the existence of involuntary unemployment. There was a conflict between what was happening in the real world and the promotion of that particular approach. I still find it extremely difficult to understand how that could have come about. It was not just that post-Keynesians were excluded for a variety of reasons from the core of the discipline, it was that the Keynesians were at the core and were expelled from it and displaced. How could it be that those ideas came on board, and to some extent the only explanation I can come up with is that the idea of optimisation had such a strong hold on a range of economists that when it was applied in the macroeconomic area it had such a strong appeal that in the end it took over. To my mind, that is not a very satisfactory explanation, and I still puzzle over how it could come about.

Could you briefly characterise the main pillars of your macroeconomic approach, what is most important within that? You could perhaps mention the basic assumptions or the economic policy implications.

It is firstly a way in which one envisages the real world, that is one envisages the actual macroeconomy as involving unemployment, poverty, or cycles in economic activity; it does not include any sort of smooth progress. It is a view of the macroeconomy which is always changing, in which there is path-dependency in that everything we do now is going to mould the future. There is no future out there waiting to be discovered, rather what we do now will help set down what the future is going to be. To some extent it starts with a particular vision of the way the economy is, and then looks to find ways of understanding and explaining that. At a more concrete level, I now approach the macroeconomy in terms of the importance of aggregate demand, in other words the basic Keynesian insights. When one looks at all the factors which influence demand, and that leads us on to, on the one side, how people go about making decisions in terms of what expenditures to make, but 
also looking at the financial system because of the way that demand is going to be financed or the effects that crises in the financial sector will have on economic behaviour. It also has to be linked in with what is a very important aspect of post-Keynesian economics, which is ideas on the interaction of supply and demand, and the importance of path-dependency. In some respects I have come to think that one of the key differences between heterodox macroeconomics more broadly and the mainstream are the issues which have to do with the interdependence of aggregate demand and aggregate supply, and ideas of path-dependency. So rather than having a neo-classical growth model in which the equilibrium growth path is essentially predetermined, one has to have the view that the path that the economy is going to follow will be gradually built up from a whole range of decisions and interactions that take place.

Do you think that the ongoing financial crisis will have a lasting impact on mainstream economics? Do you think there is a chance that post-Keynesian ideas will become stronger? Will there be a lasting impact of the crisis?

On one level it may depend on what are the perceived outcomes of the current policy experiments that are going on, particularly in the UK where the idea is now to achieve a balanced structural budget within four years. The whole analysis from a post-Keynesian perspective points in the direction that it will fail. It will fail in that it will generate high levels of unemployment. If, on the other hand, it is perceived to succeed and that it does re-establish full-employment and prosperity, then that will be strongly supportive of the mainstream view that for example fiscal consolidation can bring expansion or that there are some forms of Ricardian equivalents that work when deficits are cut so as not to affect the level of demand in the economy. The outcome of that type of experiment will be like when we look back at the I930s and see various episodes then. The US in 1937 is the best-known where there was an attempt to cut the budget deficit and it had the effect of worsening the recession. The way that those types of experiments go may well have a very strong impact, not only politically but also in terms of economic theory. When the financial crisis happened and the year or two after it there was a sense in which because theories like the efficient market hypothesis had had such a strong influence on the way that people viewed the financial markets, in turn linked to rational expectations, and they seem to have been so thoroughly disproved and undermined that it seemed that it would have to be replaced by an alternative paradigm. That new paradigm would be one based on post-Keynesian ideas, and in terms of the financial market on the work of people like Minsky. There were a number of initiatives undertaken which intended to help the replacement of that paradigm with an alternative. My sense is that the threat to the prevalence of the orthodoxy has receded, that notion that the financial crisis is strongly undermining the RARE [Rational Actors Rational Expectations] Model, that seems to have subsided. It is no longer so clear whether that will be replaced. One also looks to see what will emerge in terms of how the financial system will be analysed. Will there be a return to an essentially efficient market type of view, or whether the more Minskian view will tend to recede. In the end there may be the view that 
there has been put in place some advanced regulation to keep in check the worst excesses while things operate rather like they did before.

You already mentioned the austerity programmes all over the world, what would be your expectations? Will they work or what will be the effects of these programmes, particularly in the British case?

I could look back on the episodes of fiscal austerity and fiscal consolidation which took place in the past and in particular on those which the fiscal consolidationists have claimed were successful in the sense that not only were budget deficits brought down, but that was accompanied by falling unemployment or rising growth. There are actually rather few of those cases, but when you look at them, such as Canada in the I990s where a Io per cent budget deficit was turned into a small surplus and there was some degree of growth, then you look at what happened alongside that: Canada was entering into NAFTA with a substantial devaluation; when world trade and the US economy were booming which helped to boost Canadian exports; the savings ratio plummeted from low double-digits to close to zero. One could clearly see how budget deficit reduction was accompanied by some degree of growth through exports and consumer expenditure. From the fiscal consolidationists' point of the view the key question is whether those were fortunate accidents or systematically related to the cuts in budget deficits. I find it hard to believe that world trade or Canada's membership of NAFTA were causally linked with the budget deficits. One could perhaps argue that consumer expenditure boomed in the face of reductions in the budget deficits from some kind of Ricardian equivalence perspective, but I doubt that those who are advocating reductions in public deficits were really promoting the idea that households should take a position where they were making almost no savings at all. That was broadly speaking what happened. If we apply that to the present, looking at the usual national accounting identities, it has to be said that if the budget deficit is going to be cut, then there have to be corresponding changes in net exports or in investments or in savings. It seems rather unlikely that those necessary increases in, for example, net exports or investment, which would be required to commit the budget deficit to fall and bring some degree of prosperity are going to come to pass. It is always possible that there will be a world boom, and that many countries exports will boom as a result, but right now that seems rather unlikely. One example in terms of the UK: From the government's current forecasts, in order to get the budget deficit removed over the next four years investment would have to rise to its highest level relative to GDP in a generation; exports would have to rise twice as fast as imports; and Britain would have its first current account surplus since 1983. Those are possible, but they seem to be rather unlikely. And I could apply similar kinds of argument to other countries, so it seems unlikely that the budget deficit reductions will even succeed on their own terms let alone bring prosperity. The more likely outcome is that as each country seeks to impose its own austerity programmes they will have negative spill-over effects into other countries and there must be some danger of an accumulative downward spiral, as each country seeks to reduce its own budget deficit it tends to make budget deficits elsewhere worse. 
We have already talked about fiscal policy which plays a prominent role in your work. You advocate it by following something like the functional finance approach. Does this approach not include a problem of public debt, or why does it not in your view?

The key answer for me is that under a functional finance approach, a budget deficit is only necessary because there is an excess of private savings intentions over private investments intentions. In the absence of that excess, there is no need for a budget deficit. So the conditions under which a budget deficit is necessary are exactly the conditions under which the funds for that budget deficit would be available. It is the excess of savings over investment which is the exact cause of the budget deficit. To illustrate using one set of figures I like to quote: The government in the UK often likes to quote that it raises three pounds in tax for every four pounds it is spending, and it is borrowing one pound; what they do not say is that in 2009 for every one hundred pounds that were saved in Britain only fifty-eight pounds were invested. So there is that large gap. And indeed savings can only take place in that sort of context if there is someone who is willing to provide the financial assets for those savings, and that is indeed the government in terms of the budget deficit. Particularly when the deficit is denominated in the domestic currency, the conditions under which the deficit is necessary means that the funds will be available. The other part of the question is in terms of the public debt. Under that sort of basis, the deficit itself would have been willingly financed by the private sector because their savings would have been looking for an outlet. In that sense the public debt will be willingly held. The size of the public debt I do not see in itself as being a particular problem. It has the disadvantage that a significant proportion of public expenditure will have to be debt interest payments, but other than that the particular scale of public debt does not seem to be any problem. The UK, for example, had a public debt of over Ioo per cent of GDP for the first sixty years of the last century, and in the mid-I940s had a debt to GDP ratio of over 250. That did not prevent in any sense its economic recovery or prevent extensive nationalisation of industry in Britain. It did not, as far as one can see, form any constraint on what was done. Provided that the deficit occurs in response to a lack of aggregate demand or an excess in savings over investment, the deficit will be willingly financed. If it is not willingly financed then it suggests that savings is, broadly speaking, in line with investment and so there is no need for a deficit.

In your view what can or should be done to change the way of economic thinking or the way of economic policy? Do you think that it is necessary for heterodox economists to actively promote their ideas? It occurred to us that you are a member of the Euromemo group, and so there seems to be quite some political impetus that you have. Do you think that is something good for economists, or is something that should be done by economists?

On one level it has to be an individual's personal choice. It does not have to be any kind of requirement. If one comes to study economics, which in some grandiose kind of way I did, in terms of on the one hand wanting to understand how the world works, and on the other hand to suggest or promote ways in which it might work better, however one defines that, then it seems almost pointless studying economics unless one is going to in some form 
promote ideas which you think are going to lead to a better set of policies, to better outcomes, or improved economic welfare. From my point of view there is an intention that one studies economics in order to arrive at understandings of the world and to promote ways in which things could be better. That does mean getting involved in policy debates and advocating certain sets of policies and trying to bring them about.

The interview was conducted by Stefan Ederer and Achim Truger in October 2010.

\section{Selected Publications of Malcolm Sawyer}

Theories of the Firm (Weidenfeld and Nicolson and St. Martin's Press, 1979) - Economics of Industries and Firms: Theories, Evidence and Policy (Croom Helm (now Routledge) and St. Martin's Press, I98I; second edition 1985) • Macro-economics in Question (Wheatsheaf Books and M.E. Sharpe, 1982) • Business Pricing and Inflation (Macmillan and St. Martin's Press, 1983) - The Economics of Michal Kalecki (Macmillan and M.E. Sharpe, 1985) - The Challenge of Radical Political Economy (Harvester Wheatsheaf and Barnes and Noble, 1989) - Unemployment, Imperfect Competition and Macroeconomics: Essays in the Post Keynesian Tradition (Edward Elgar, 1995) - How Many Cheers for the Tobin Financial Transactions Tax? (Cambridge Journal of Economics, I997, 2I(6)) (with P. Arestis) • Keynesian policies for the new millennium (Economic Journal, 1998, I08) (with P. Arestis) - A Future for Public Ownership (Lawrence and Wishart, 1999) (with K. O’Donnell) • The Euro: Evolution and Prospects (Edward Elgar, 200I) (with P. Arestis and A. Brown) - Kaleckian Money and Finance (The European Journal of the History of Economic Thought, 8(4), Winter 200I) $\bullet A n$ alternative stability pact for the European Union (Cambridge Journal of Economics, 200I, 25 (I)) (with P. Arestis and K. McCauley) - The NAIRU, Aggregate Demand and Investment (Metroeconomica, 2002, 53(I)) • Re-examining Monetary and Fiscal Policies in the Twenty First Century (Edward Elgar, 2004) (with P. Arestis) - Aggregate Demand, Conflict and Capacity in the Inflationary Process (Cambridge Journal of Economics, 2005, 29(6)) (with P. Arestis) - A Critical Reconsideration of the Foundations of Monetary Policy in the New Consensus Macroeconomics Framework (Cambridge Journal of Economics, 2008, 32 (5)) (with P. Arestis) - The Tragedy of UK Fiscal Policy (Cambridge Journal of Economics , 2012, 36(I)) - The Kaleckian Analysis of Demand-led Growth (Metroeconomica, 2012, 63 (I)) 